\title{
Pentecostals in the BSSR: An Alternative Way of Life in a Hero-Society After Stalin
}

\author{
BY \\ THOMAS M. BOHN and RAYK EINAX
}

Soviet everyday life finds only a partial reflection in the archives. Those who are interested in the fate of common people have often to consult the reports of bureaucrats, which focus on behaviour that deviates from the official norms. When searching for forms of sociality and community in state socialism, it becomes clear that a "civil public sphere" did not exist at all. Consequently, the ambivalence of "party public" and "private sphere" provoked, in fact, schizophrenic forms of behaviour, which in retrospect are hard to discern. But the "stubbornness" of the broader masses of people remained for the organs of state security an unresolved problem (Shlapentokh 1989; Vajl and Genis 1998; Yurchak 2005).

In this context, religious communities and sects, whose history is even today only partly known, seem to be a promising field of research (Shirley and Rowe 1989; Basse and Stricker 1989; Ramet 1993; Anderson 1994; Davis 1995). How we can do justice to groups which left no testimonies of their own and of whom we know only through the files of the Soviet surveillance state? We are only able to tease out options of agency, which are located in a coordinated system of diverging interests of participating subjects. While the party elite basically aspired to ban religious life for the public, believers sought for an escape from the self-declared atheistic Soviet society. It was the Commissioner for the Affairs of Religious Cults who was responsible for controlling the activities of religious communities. These communities risked marginalisation or stigmatisation by the authorities for worship and other religious activities.

In this case, Actor-Network-Theory may offer us some help. Bruno Latour developed the hypothesis that the autonomy of human actors (that is "actants") is limited by disruptive factors from non-human actors, which are subject to accidents and therefore confront any determinism with a kind of arbitrariness. Due to an inevitable achievement of adaption, human beings and things constitute a relationship, which is then regulated by alliances with other networks. From this perspective, it is possible to explain, for instance, the limiting of human freedom 
of action by the influence of technologies or the disciplining of people through various instruments of administration (Belliger and Krieger 2006; Latour 2007).

Local studies offer a fecund ground to apply the insights of Actor-NetworkTheory to the question of agency. For this reason, this study is devoted exemplarily to the situation in the Belarussian capital Minsk during the period of de-Stalinisation (1953-1964). Under this premise the following problems shall be discussed: Did the Belarussian Socialist Soviet Republic (BSSR) offer freedom of action for independent interest groups? Within what limits was the activity of nonconformists circumscribed? Why were unofficially-acting religious communities neither fully nor effectively forbidden by the Party and State?

It was the Pentecostals - much more so than intellectual dissidents - who, with their perseverance and "moral courage", represented "courage" one of the biggest challenges for the Soviet state at its periphery. Focusing on the reports of the Commissioner for the Affairs of Religious Cults we want to discuss "stubbornness" and "resistancy" as alternative categories to "agency" first. Then we shed light on the Soviet Pentecostals in general, followed by a historical sketch about the fast-growing Belarussian capital Minsk during the relevant period. In the central part of our article we try to offer an interpretation of the interaction between the Commissioner and the Pentecostals in Minsk. We resume with the problematic existence - for both party and state officials - of bold believers on the city's outskirts who the authorities never could entirely control, be it because of the clandestine character of the Pentecostal movement or because of internal quarrels between different bodies.

\section{Agency or Stubborness and Resistance?}

For a long time, the research on Communism has been inspired by Hannah Arendt's thesis that both the Stalinist and the National Socialist dictatorships resulted in an "atomisation of society" (Plaggenborg 2006). According to this opinion, only the intellectual dissent which was able to develop under the conditions of the cultural "thaw" under Khrushchev stimulated renewed communitisation (Alexeyeva 1985; Beyrau 1993; Stephan, 2005). Nevertheless, when considering matters through this lens, Moshe Levin's thesis should not be neglected: he argued that due to migration Soviet society had constituted itself as a "quicksand society" which, despite rigorous compulsory registration, the bureaucracy found difficult to tame (Lewin 1985; id. 1991a; id. 1991b).

Social protests during the post-Stalinist period, apart from people's risings in the Eastern Bloc, particularly the hunger revolt of Novocherkassk, have repeatedly attracted the attention of researchers (Schlögel 1984; Baron 2001; Kozlov 2002). 
Recently, the mood of the Soviet population in the post-war period and the development of public opinion in the period of "de-Stalinisation" have also become objects of discussion (Zubkova 1998; Id. 2000; Grushin 2001; Id. 2003-2006; Aksiutin 2010). In any event, unlike the processes of communisation, the regime certainly did not wish to foster any kind of individualism; just the opposite: it established new forms of social control using the emergence of a future communist society as a perennial justification. Many of the utopian projects of the Khrushchev era can only be understood in the light of his firm belief in a communist society that was taken to be just around the corner (Bohn and others 2014, 24).

In the course of the foundation of a socialist welfare state under Brezhnev there was the attempt - as stated by Victor Zazlavsky's stimulating thesis - to tie the population to the regime through "organised mass consensus". As long as there was the guarantee of a job and price stability, for the people of the Soviet Union the "retreat to the private" was an ever more wide-spread option (Zaslavsky 1994). In this context, the dichotomy between private sphere and public space widened which is said to have resulted in schizophrenic behaviour patterns in socialist systems - and this has repeatedly been pointed out in research. Counter-publics, as constituted by religious interest groups and political dissidents, it is said, must be distinguished from the party public (or the public of meetings) on the one hand, and the fragmented public of association public on the other (Zaslavsky 1994).

In this context, Soviet society was largely shaped by individual restrictions. Various supervisory bodies controlled the observance of official regulations that offered only a few open spaces. The intense pressure to conform meant that the state power classified any action relatively quickly as non-conformist behaviour. Particularly rapid social change (industrialisation, migration, urbanisation etc.) was decisive for the increase of deviant patterns of behaviour. Nonetheless, the strict Soviet set of behavioral norms was consistently subverted by citizens in their day-today life. This performance later on provided the social foundation for the emergence of diverse subcultures but did not necessarily mean a conscious resistance against the Soviet system. From the point of view of the history of everyday life, the time has come to employ new categories for the analysis of non-conformism or dissent in Communism. In this case, reflections about the German experience with the "SEDdictatorship" offer new insight for researching Soviet traditions.

"Resistancy" and "resistant behaviour" promise dissent or non-conformism. Furthermore, these terms mark a difference from all forms of open or politically motivated "resistance" or opposition which have long been the focus of historiography. For the research on national socialism, Martin Broszat introduced the term "resistancy" (Resistenz). This way he wanted to make obvious that the regime had not only to fight against political opposition by representatives of 
the workers' movement and the conservative elites but also that the bulk of the population remained immune to its structure of norms and values. To say that everyday life in socialism, with its different ways of behaviour in the public and private spheres, was schizopherenic seems to be the appropriate label. Although Broszat had revised the purely political-historic approach, his critics confronted him with the accustion that despite partial resistancy the regime had, on the whole, met broad approval among the population (Broszat 1981, Id. 1987). ${ }^{1}$

For the research on the German Democratic Republic, Ilko-Sascha Kowalczuk summarised the terms resistance and opposition by the formula of "resistant behaviour" (widerständiges Verhalten). Kowalczulk started out from the premise that every individual is able to undergo a situation-appropriate metamorphosis from being an accomplice to being a saboteur or vice versa. On this basis he described a canon of ways of behaviour - ranging from "social refusal" through "social protest" to "political dissent" at the end of the spectrum - which questioned, restricted or contained the Party's claim to power. "Social refusal" was reflected by the conscious or unconscious boycott of official conventions, such as not taking part in demonstrations. "Social protest" was expressed by moaning about everyday evils, be it in the form of strikes or in the form of petitions. "Political dissent" had been expressed threefold: until the building of the Berlin Wall, the anti-Communist opposition had supported traditional middle-class values.

After the building of the wall, a socio-cultural or societal opposition which was based on milieus and interest groups developed. Furthermore, during the entire existence of the GDR a reform-Socialist opposition had been active in making itself heard. Finally, "mass protest" had occurred only in the years 1953 and 1989 (Kowalczuk 1995a, Id. 1995b).

As an alternative set of tools, besides the categories of loyalty and dissent, the category of "stubbornness" (Eigensinn) suggests itself. Alf Lüdtke used this term to describe the history of the everyday life of workers before 1945, and Thomas Lindenberger used the term in analysing the history of the GDR. Lüdtke, when describing the phenomenon, made a reference to history in the form of comparison with the educational programmes of the Enlightenment era, and according to this diction described stubbornness as a counter-term to discipline and sociability. The heuristic value of the term, he stated, is in aiming at a sphere somewhere between power and resistance while focusing on spontaneous practices and ways of behaviour (Lüdtke 1993; Id. 1994). In this context, Lindenberger pointed out, stubborn behaviour had been less motivated by conscious resistance than by personal interests, and that such behaviour had first of all been tied to roles and situations (Lindenberger 1999, 21-26).

1 From a comparatist point of view see Eckert 1995, Kleßmann 1996, and Stöver 1997. 


\section{The Pentecostal Movement in the Soviet Union}

In this respect, sectarianism in the USSR represents a fitting example (see among others Kalugin 1962; Sovremennoe Sektantstvo 1961; Fedorenko 1965). Among those officially listed as "sects" were were not only the officially "unwanted" denominations like the Pentecostals, but also Baptists, evangelical believers and Adventists. The Pentecostal movement had its roots in the United States at the beginning of the 20th century and reached the Soviet Union as early as the first half of the 1920s. Under Stalin, "Christians of Evangelical Belief" (khristiane very evangel'skoi) were repressed like followers of other religious communities. However, in 1939, after the Soviet occupation of eastern Poland, a certain number of additional parishes emerged. Coming from Belarus and the Ukraine, their agitation spread through exile to the GULAG-camps all over the Soviet Union.

After the outbreak of the Second World War, Soviet religious policy underwent significant changes. In this context, the regime tried to strengthen control over Protestant congregations by centralisation of the church hierarchy: 1944 brought the unification of the Evangelical Christians with the Baptists. In 1945, the Pentecostals were incorporated into the All-Union Council of the Evangelical Christians-Baptists (Vsesoiuznyi sovet evangel'skikh khristian-baptistov). The so-called August Convention provided baptism through the Holy Ghost with or without the precondition of speaking in tongues, but forbid glossolalia in public ceremonies. Under these circumstances, one half of the Soviet Pentecostals refused unification with the officially registered Evangelical Christians-Baptists and preferred a life of illegality instead.

In January 1957, a new attempt at uniting the two groups was undertaken as the leadership of the Union met with the (moderate) spokesmen of the Pentecostals. But many of their parishes chose to stay away as before. Nevertheless, there were approximately 600 groups with 25,000 members legally operating on the territory of the USSR in 1959-60 - with official registration, that is - against roughly 14,000 Pentecostals who refused to do so (D’iachenko 2003, 61). The latter could only meet as a group illegally. That is why they conspired to isolate themselves as completely as possible.

The revival of religious prosecution under Khrushchev consisted primarily of the intensification of atheistic propaganda and intensified repression of the church hierarchies. Consequently, in 1960 the All-Union Council of Evangelical ChristiansBaptists adopted a new charter for its congregations and appropriate instructions for the parish councils, this charter envisaging a reduction of missionary activities and the restriction that sermons could only be preached in registered buildings and not in private houses. 
Under the new guidelines, baptism would need to be postponed until the indivudal being baptised has reached their 30th birthday, and even then this was only allowed after a minimal membership period of three years, childcare and youth ministry was ended, contact with neighbouring congregations was limited, and the number of musical instruments used during divine service was reduced. Although these instructions underwent a revision at a union-wide conference in 1963, the illegal "Union of Congregations" split from the All-Union Council of Evangelical Christians-Baptists and created its own council. In reaction to these developments, the Pentecostals remained sceptical.

In the 1970s, they received attention in Western media, since a few of them tried to enable their emigration from the Soviet Union by fleeing to the American embassy. The Kremlin then took measures to prevent the expected exodus of Pentecostals by permitting autonomous congregations of Evangelical Christians (Lane 1978; Sawatsky 1981; Alexeyeva 1985; Fletcher 1985; Istoriia evangel'skikh khristian-baptistov 1989; Hollenweger 1997). In the light of the international policy of detente and the influence of a global public during this period, the supposed totalitarian state found it easier to turn a blind eye and to accept the sectarianism of an unimportant minority group than risk a scandalous conflict with radicalised believers. $^{2}$

Looking for religious inspiration beneath Marxist ideology, and a way of life apart from Soviet conventions, the behaviour of the Pentecostals was indeed resistant towards the approaches of their responsible state Commissioner, their "controller". The Pentecostals chose to do this by switching between the boundaries separating the private and the official sphere in communication with the Commissioner. Aware of the rules of Soviet life and the limited power of the authorities, they used the party slang and and spoke in the true sense of the word "Bolshevik". On the other side, the Commissioner was left, due to the limits of his power and influence, virtually in despair over their stubbornness.

\section{The Metamorphoses of Minsk from "Socialist City" to "Hero City"}

In the framework of the Soviet reconstruction programme after the Second World War, the BSSR finally underwent a period of rapid industrialisation and urbanisation. The planners concentrated most of the country's resources on rebuilding the capital, Minsk, which had been largely destroyed during the German occupation. From 1947 to 1950, a tractor factory, a truck factory and a bicycle factory started production. Minsk became the centre of the Soviet automotive

\footnotetext{
${ }^{2}$ Compare: Kotkin 1995, 198-237.
} 
industry, in which private transport played only a secondary role. Under these conditions, the population quadrupled from a quarter of a million in 1950 to one million in 1971.

In connection with this development, a radical population change took place. On the one hand, as a consequence of the Holocaust, Minsk lost its character as a Jewish shtetl, which had persisted through at least the first decade of Soviet rule. On the other hand, the organised recruitment of a workforce from the countryside and the immigration of apprentices from the provinces provoked a ruralisation of the urban society. Inevitably, the reconstruction of the "Socialist City" was accompanied by a number of contradictions.

While the city centre was filled with neo-classicist triumphal architecture, the infrastructure in the neighbourhoods remained underdeveloped. Since state enterprises had to fulfil the production figures of the five-year plans under unfavourable conditions, they hesitated to waste energy on residential housing construction. The private sector compensated for the needs of the city population through the erection of villages with wooden houses on the territory of the city. As the 1950 s turned into the 1960 s, more than 100,000 people were living in private houses without running water. Under these conditions, the majority of the people experienced a level of social misery that reflected that of the "Capitalist City" described by Marx and Engels. In other words, Minsk at this time still had a dual character and was open for different lifestyles. While an educated minority tried to participate in the Soviet way of life, the majority continued to practise traditions brought from the countryside. ${ }^{3}$

Since the beginning of the 1930s, planners in the Soviet Union claimed a "sanitary norm" of nine square metres of individual dwelling space per person, which was over and above the communal-use space occupied by a kitchen, corridor and bathroom. On average the size of dwelling space in Minsk in the decade from 1950 to 1960 increased from only 5.8 to $8.4 \mathrm{~m}^{2}$. In 1960 , there were 80,000 people who did not have access to any living space of their own officially registered. As many as 42,000 people only had less than four square metres of individual dwelling space available to them. These people came from migrant communities and so could not obtain a "residence permit" (propiska) in the city due to this failure to fulfil the sanitary norm. Indeed, two percent of all inhabitants therefore lived in the city beneath the threshold of legality.

All in all, from the end of the Second World War to the dissolution of the Soviet Union, the population of Minsk had to manage their affairs in the face of a number of shortages. For over two decades, the idea of enjoying a flat of one's own

The following remarks refer to Bohn 2008 (in Russian: Bon 2013). Concerning deStalinisationStalinization in particular, compare: Bohn 2014. 
in a modern apartment building represented a utopian ideal. While in the 1940s residence was possible for many residents only in barracks or ruins, by the $1950 \mathrm{~s}$ people had to find a place in a communal apartment (kommunalka), or a dormitory (obshchezhitie), or as a lodger in a wooden house.

Only at the end of the 1960s did young families have justification to dream about a modest flat with central heating and sanitary facilities. Even in the 1960s and 1970s, it was obvious that the misery of residential housing - even after the announcement of the mass building programme in 1957 and after the propagation of a solution of the housing problem within two decades in the party programme of 1961 - still represented the main social question. Around 72,000 families were looking for housing and another 26,000 families, who were living on potential building sites or in ramshackle huts, had to be evacuated. Nevertheless, the urban transition from the mikroraion, from neighborhoods consisting of buildings made with precast concrete slabs, to monotonous satellite cities with high-rises at the outskirts of the town, enabled a statistical availability of nine square metres of individual dwelling space per person in the 1980s. In sum, social life was dominated by the need for dwelling space.

On the one hand, modernisation played an important factor for the secularisation of society. On the other hand, social control was rather ineffective in a situation in which thousands of people did not enjoy normal conditions. It meant that the areas of private wooden houses still offered a shared environment for individual decision-making outside of the party public.

Against the background of the erosion of the communist utopia and the propagation of the Belarussian "Partisan Republic" in the 1960s, a metamorphosis of Minsk's image from the "Socialist City" to the "Hero City" took place. On the one hand, Nikita Khrushchev and Leonid Brezhnev, during the "thaw" and deStalinisation, as well as "developed socialism" and neo-Stalinism periods, were looking for a consensus with the people. In their social policy, they tried to fulfil expectations concerning dwelling and consumption; in their state ideology, they appealed to antifascist and pacifist moods.

On the other hand, the Belarussian party leader Piotr Masherov was interested in the emancipation of the BSSR from the Kremlin. In this atmosphere it should come as no surprise that Minsk received the title of a Soviet "Hero City" following only Stalingrad/Volgograd, Leningrad, Kiev, Odessa, Sevastopol, Moscow, the fortress city Brest, Kerch and Novorossiysk. Due to permanent differences between Masherov and Brezhnev the presentation of the award was postponed until June 1974 on the occasion of the 30th anniversary of the liberation of Belarus from German occupation. While the partisan myth was based on a rebellious atmosphere, the antifascist ideology functioned only as a formal convention. People mainly 
ready to make their deal with the party and the state. The rule was for political indifference in return for the guarantee of a workplace and for the assignment of a one-or two-room apartment.

\section{Problems Controlling the Religious Underground}

The Pentecostal movement arrived in Belarus before the Second World War. The believers' way of life did not correspond by any means with the conformity the Soviet state expected from its citizens. Preaching, biblical exegesis and spiritual prophecy worked to discredit the "sect". Furthermore, its followers boycotted the elections for the Soviets numerous times. At least since the mid-1950s the Belarussian authorities had critically observed that everywhere, but especially in village settlements, there was a continuous increase of Pentecostal activity. This was fuelled, after the death of Stalin, by the return of many of their activists from imprisonment or life underground.

In many places new parishes were initiated, sometimes for a short period under the guise of the Union of the Evangelical Christians-Baptists. In contrast, the BSSR Commissioner for the Affairs of Religious Cults issued a decree in 1954 and later (1956) detailed instructions that categorically prohibited his local deputies from the registration of Pentecostals as official legal parishes. Moreover, they also adopted measures to suppress the Pentecostals' illegal activities. ${ }^{4}$

That is another reason why, for the "Hero City" of Minsk, the activities of the Pentecostals are documented only in the reports of the BSSR Commissioner for the Affairs of Religious Cults, ${ }^{5}$ who was answerable to the Council of Ministers of the BSSR in Minsk as well as to the Council for the Affairs of Religious Cults in Moscow. ${ }^{6}$ Until their unification in 1966, two separate offices had jurisdiction over religious activities: the Commissioner for the Affairs of the Russian Orthodox Church, and the Commissioner for the Affairs of Religious Cults. Both acted together as state authorities and controlled in this regard the strict observance of religious legislation - this applied to the local executive committees as well as to the single parishes.

In cases of violations they had to intervene immediately. The authority's administration was, of course, bound by the ideological premises of the party that aimed for an elimination of religious remnants, at least in the public sphere. Accordingly, officials interpreted the legislation arbitrarily. In addition, the

\footnotetext{
${ }^{4}$ Concerning the Pentecostals in the BSSR see D'iachenko 1999. These publications pretend to be current while resembling in argumentation closely the clichés of Soviet times.

5 See among others: Anderson 1991; Luchterhandt 1993. For the recent discussion of the corresponding archival sources - from an anthropologist's perspective - compare Luehrmann 2015.

6 Compare Vysshie organy 2003, 193-204.
} 
Commissioners dealt with the statistical acquisition of the parishes (and sects), prayer houses and clergymen within their domains. All this information had to then be forwarded to the responsible party and state authorities.?

In the district of Minsk in the first half of the 1960s, A. Ponomarev was the Commissioner for the Affairs of Religious Cults, and in the second half A. I. Logvinenko was the Commissioner for the Affairs of Religion. The style of their reports indicates that both were persons of higher education. Sometimes the writer described the scenery with a certain sense of irony. They, obviously, fulfilled their duties with a lot of pedantism. On the whole, their jobs did not demand too much from them. Only the Pentecostals caused some trouble: although the Commissioner repeatedly reported that the Pentecostals lacked any respect for the authorities, he did not find any agent in the whole Soviet state apparatus that was ready to repress "blessed fools". What were the complaints of the Minsk officials?

In connection with the intensification of anti-religious propaganda in the Khrushchev era in the middle of the 1950s, for the first time after the war, the activities of the Pentecostals, which were independent from the Evangelical Christian-Baptists, were registered in Minsk (Gosudarstvennyi Arkhiv Minskoi Oblasti (GAMO), f. 3651, op. 2, d. 5, 11. 54-62). Systematic control indeed took place only in the framework of the union-wide church prosecutions after the extension of the city borders and the incorporation of illegal settlements of wooden barracks in 1959.

In the worker neighbourhoods of the southeastern industrial quarter, as well as in the former villages Drazhnia and Stepnianka in the east of the city, three groups totaling 120 persons were based. One group consisted of nearly eighty people and worked like its leader Nikolai Kibalko, who was a motor vehicle lathe operator, working mostly in a Minsk tractor factory. They gathered mostly in the house of Kibalko, who soon integrated the two other groups under his leadership. Witnessing the expansion of the Pentecostals' community, Ponomarev concluded that counteraction by all relevant organisations and police departments had lessened. In view of this situation, he considered, alongside "individual influencing" (of leaders and believers), the operation of so-called "street and neighbourhood committees" and auxiliary police to be of most use as responses (GAMO, f. 3651, op. 2, d. 9, 11. 6-8; GAMO f. 69, op. 1, d. 1467, 11. 5-6, 15-16; GAMO f. 3651, op. 2, d. 9, 11. 98-99).

Shortly afterwards the Committee for State Security (KGB) department in Minsk found evidence that the Pentecostals planned to hold a religious service in a private home on New Year's Eve in order to welcome the new year 1961. In

7 Concerning religious policy in the BSSR see Einax 2014. 
advance, a string band practised, while youngsters rehearsed psalms, short stories and poems with religious content. A tape recorder was to play sermons, songs and hymns. The Minsk party committee was responsible for leading the quashing of this gathering. The owner of the house was summoned to the militsiia in order to have a debate of a "prophylactactical character" and to make him aware of his proposed violation of the religious legislation. Moreover, auxiliary policemen were delegated to instigate a conversation with the wife and sectarians who. in preparation for the celebration, had gathered already. On this occasion, the recorder and the tapes were confiscated. After listening, the KGB's suspicions about the politically harmful character of some of the preaching were confirmed; the taped services were also (audibly) frequented by infants (which was forbidden by law). The seized recordings were therefore to be utilised for the 'subversion' of the sects and for the "compromising" of its leaders (GAMO, f. 69, op. 1, d. 1537, 11. 1-2).

The Pentecostals consisted of workers from the generation born in the 1930s who followed a traditional village way of life. As the main reason for the departure from the Evangelical Christian-Baptists they spoke of how the house of prayer of their competitors was closed to children. Since their own congregation was not officially registered, they missed the opportunity to open a house of prayer of their own. For this reason, religious assemblies had to take place illegally in private houses. The whole congregation met every first and third Sunday of the month, while on the other days of the week five to ten people gathered together in the morning or in the evening. A disciplinary enquiry at Kibalko's workplace could not really shock them. After the schism of the Evangelical Christian-Baptists, the congregation of the Minsk Pentecostals created their own management body. Kibalko was chosen as Presbyter, the carpenter Vladimir Zemlevich and the fitter Mikhail Pocherniaev as Deacons and the lathe operator Leonid Goncharenko as Chairman of the youth club.

The problems of the Commissioner began in earnest with the illegal institutionalisation of the Pentecostal congregation. As a state official he was obliged to indicate the danger sects posed to the public order. Accordingly, he declared that the conscientious objection of his clientele contradicted Soviet patriotism. Furthermore, he stated that the eccentric speaking in tongues at the ceremonies of the Pentecostals caused a noise that disturbed neighbouring children while they were doing their schoolwork. But the true powers of the Commissioner remained limited: he considered a mere citation of the sect leaders and extreme fanatic members as helpful in order to inform them, once again, about their illegal practices. In this case, he stated, they should be advised to look for registered prayer houses and to obey the statute of the All-Union Council of the Evangelical Christians-Baptists. A registration as Pentecostals was impossible in 
any event since their activities would not be sanctioned by the Soviet constitution and lesser laws.

In this context, the philanthropic and social engagement and activity of the Pentecostals is remarkable. They managed to organise a youth music group, helped people in need and established ties with believers across the whole of the Soviet Union. For instance, they took care of a paralytic woman and her five-year-old daughter who, despite her state pension and despite the supplement of groceries from the child's father, could not live without additional help. The Pentecostals not only offered a nurse, but also took over the regulation of public affairs and even renovated the roof of their wooden house. Later on, they organised a youth meeting with participants from Latvia, Ukraine and Moldavia in April 1961, indicating, in this way their union-wide connections.

Of principal interest is the fact that, apart from their illegal organisation and religious practice, the Pentecostals did not commit any crimes. Only one Pentecostal was identified as a criminal. During a stay at the tractor factory's polyclinic this individual was so angered about the loss of his Bible that he began accusing and giving offense to bedridden roommates (despite the late hour) and the medical staff, and so the appearance of the police became necessary. An investigation was initiated and the "troublemaker" brought to trial where he was sentenced to one year in prison for "hooliganism". In other words, the Pentecostals were always confronted with defamation. A seventy-year-old pensioner was rumoured to have influenced a kindergarten teacher and the wife of an officer to read the Bible. It was alleged that the pensioner told the young lady that she should be ready to bring her thirteen-year-old daughter forward as a "victim" like Abraham did to his son Isaac in the Old Testament (GAMO, f. 69, op. 1, d. 1537, 11. 22-24).

The Commissioner tried two approaches to free himself from such troubles. First, as described below, he invited the speakers of the Pentecostal congregation to a meeting where he warned them that they needed to make sure that they observed religious laws, and to encourage them towards a unification with the Evangelical Christian-Baptists. However, he could not find a common language with people who were only afraid of the Last Judgment. For this reason, he concentrated his hopes on convincing them to change their positions regarding the Evangelical Christian-Baptists. Secondly, the Commissioner tried to convince the party and the police to forbid all Pentecostal activity and to prevent their activities by bringing them to court. Thus, in a report written in the summer of 1961 Ponomarev pointed out that Kibalko and other persons had conducted conspiratorial acts as well as illegal baptisms.

Several debates with the delinquents did not lead to the desired results. The Pentecostals would continue "crippling Soviet people spiritually and in humiliating 
them". Since the leaders' actions were seen as causing harm to the health of Soviet citizens they were to be charged by the regulations of the new criminal code. Despite this, the Commissioner had to wonder about the fact that no instance brought his concern enough attention from the relevant authorities. The state demanded only occasional monetary fines from the Pentecostals for the organisation of illegal gatherings and formally condemned only conscientious objectors (GAMO, f. 69, op. 1, d. 1537, 11. 27-28).

In November 1965, a delegation of nine people asked the Commissioner in vain for an official registration of a Pentecostal congregation with over one hundred members (GAMO, f. 69, op. 6, d. 400, 11. 4-8). Three years later, in the autumn of 1968, Kibalko begged the head of the congregation of the Evangelical ChristianBaptists for the use of the prayer house for two or three days per week without the desired result (Report of the Commissioner for the Affairs of Religion in Minsk from 19th March, 1968. GAMO, f. 812, op. 1, d. 9, 11. 100-108). As a consequence of this development, the Commissioner - after a talk with the Pentecostals Nikolai Kibalko, Vladimir Goncharenko, Mikhail Pocherniaev, Vasili Marchenkov, Ivan Raduta and Fedor Burak in February 1970 - reported different opinions among the members regarding the alternative of an affiliation to the Evangelical ChristianBaptists, or preservation of their independence from them. Following the report of the Commissioner, Kibalko pronounced that it would be an indignity to define meetings with prayers as falling under the remit of political crowds. He refused to see himself as an "underground fighter".

The rituals of the Pentecostals did not, actually, differ in essence from the rituals of the Evangelical Christian-Baptists. Goncharenko, Pocherniaev and Marchenkov claimed that their religious activities did no cause harm to anyone. Lenin's decree "About the separation of the church from the state and the school from the church" by guaranteeing the freedom of conscience and allowing believers all possible opportunities to practise their religiousness but forbidding the teaching of religion in schools also took from them the chance to educate their children. As a result, Soviet youth living in many areas would not know any kind of morality (GAMO, f. 812 , op. 1, d. 23, 11. 108-115).

Here the Pentecostals had touched upon a sensitive nerve. According to Soviet doctrine, the abandonment of religion was to come about by the state's monopolisation of the schooling of children and youngsters. The Commissioner for the Affairs of Religion hesitated to go further by introducing active repression of the group. His hope of dividing the Pentecostal movement was an illusion. Once the number of Pentecostal believers reached 400 in the middle of the 1970s, the Commissioner finally gave up his fight and recommended the legalisation of the congregation to the state and party leadership. He rationalised his decision with 
the argument that the activities of the Pentecostals would be easier to control this way, especially in the event that plans to move them to the prayer houses of the Evangelical Christian-Baptists proved successful (GAMO, f. 69, op. 12, d. 26, 11. 40-44; GAMO f. 69, op. 13, d. 33, 11. 6-20).

\section{Belarussian Pentecostals as a Community/Network of Stubborn Individuals?}

In 1960, the authorities officially recorded roughly one hundred groups of Pentecostals in the BSSR in total, including sixty-eight groups in the (western) Brest region. ${ }^{8}$ In this context, the government agencies, especially in the capital Minsk, began to act quickly- from the Commissioners for the Affairs of Religious Cults, to the KGB - this affected all who were involved in the struggle against sectarianism. The state institutions were above all obliged to record all groups of Pentecostals statistically. Some of these groups were subsequently liquidated by force, followed in 1962-63 by court proceedings against the clergy; in total eighty-five people were sentenced for their "parasitic lifestyle" (Article 222 of the Criminal Code of the BSSR). Others were imprisoned or banished for violations against the Soviet legislation of religious cults, or for "antisocial machinations." Hence some groups broke up, so that following the official count of 1965 there still existed forty-three Pentecostal parishes with 1,938 members (D'iachenko 1999, 25; id. 2003, 59). ${ }^{9}$

With regards to Minsk, the Pentecostals obviously distinguished themselves by a combination of their postulation of a free will with the ideals of religious education and honest work. Their eschatological worldview inclined them to contemplation and social isolation, but they understood their missionary task also as an obligation to fulfill philanthropic duties. Although sectarians found a home in the Belarussian capital, they wanted to live in the underground of the Soviet Union. Accordingly, the Pentecostals should be seen as "religious dropouts".

Conflicts with the Soviet authorities resulted, on the one hand, from the fact that, as a non-registered congregation, they were forced to organise meetings illegally. On the other hand, their pacifist attitude forced their young men to refuse any military service with weapons. In any case, the Pentecostals could be active in the Belarussian capital with relative freedom, since their low numbers enabled them to enjoy a kind of "jester's licence" and because constitutional legality in post-Stalinism again exerted a certain influence. Civil courage or the roots of civil society in the history of Belarus are to be found less in the actions of the Intelligentsia than in the resistance and stubbornness of the common people.

\footnotetext{
Compare: Prichiny sushchestvovaniia 1965, 194.

9 See also Sbornik zakonov 1969, 94.
} 
In the view of Bruno Latour (and his Actor-Network-Theory), one interest group in Minsk created the myth of the "Partisan Republic" and another believed in the coming of the Last Judgment. While the party tried to convince their members to adopt a communist morality, the Pentecostals found their motivation in a certain variety of the Protestant ethic. Therefore, due to the contradictions of their separate dogmas, there could not exist any understanding between the two groups. Accusing them of infantile behaviour party, officials did not respect the Pentecostals or take them seriously. The Pentecostals did not listen to the warnings of the Commissioner for the Affairs of Religious Cults, who without success defamed the youth group and the conscientious objection as offenses on the reason of state. In accordance with his official instructions he changed his strategy, which foresaw initially prohibition, and then division and legalisation.

Confronted with the ignorance of the party and the stubbornness of the Pentecostals the Commissioner had no other choice than to change the focus of his activities. His main interest consisted in combining a guarantee of public order with a renewal of calmness in his role. Therefore, from them on, he dealt with the Pentecostal problem more tolerantly. As far as Agent-Network-Theory is concerned, developments were dictated by the Pentecostals' need for official registration, and the Commissioner's obligation to write reports on public order. In any case, a group of one hundred people in a city with one million inhabitants could truly bother only one person or office. Therefore, the category of "stubbornness" offers more perspectives for the writing of the history of everyday life under state socialism than the concepts of Bruno Latour.

\section{Conclusion}

From our case study we can draw the following conclusions. First, the Pentecostals comprised an illegal community, who constituted an independent interest group or a non-government organisation, and whose missionary task included pedagogical aims. Secondly, the existence of phenomena like the Pentecostals indicates that even if "totalitarianism" is a popular term in post-Soviet historiography, we should be aware of its mythological elements which exclude questions of responsibility for the development of authoritarian regimes (Kaściuk 2000; Kostjuk 2002). Finally, although Minsk, after the breakup of the Soviet Union, is still associated with the image of a "Hero City", it is worth mentioning not only the partisans of the Second World War, but also the names of the protagonists of the Pentecostal movement: Nikolai Kibalko, Vasili Marchenkov and Vladimir Goncharenko. ${ }^{10}$

${ }^{10}$ See also Einax 2011; Id. 2011. 


\section{References}

\section{Archival Collections}

Gosudarstvennyi Arkhiv Minskoi Oblasti (GAMO).

f. 69 , op. $1,6,12,13$.

f. 812 , op. 1 .

f. 3651 , op. 2 .

\section{Secondary Sources}

Aksiutin, J., 2010. Khrushchevskaia ,ottepel'“ $i$ obshchestvennye nastroeniia v SSSR v 1953-1964 gg. 2-e izd., ispr. i. dop. Moskva: ROSSPEN.

Alexeyeva, L., 1985. Soviet Dissent. Contemporary Movements for National, Religious and Human Rights. Middletown CN: Wesleyan University Press.

Anderson, J., 1991. The Council for Religious Affairs and the Shaping of Soviet Religious Policy, in Soviet Studies, 43, pp. 689-710.

Anderson, J., 1994. Religion, State and Politics in the Soviet Union and Successor States. Cambridge, New York, Melbourne: Cambridge University Press.

Baron, S. H., 2001. Bloody Sunday in the Soviet Union. Novocherkassk 1962. Stanford CA: Stanford University Press.

Basse, O., and Stricker, G., eds. 1989. Religionen in der UdSSR. Unbekannte Vielfalt in Geschichte und Gegenwart. Zollikon: G2W Verlag.

Belliger, A., and Krieger, D. J., eds. 2006, ANThologie. Ein einführendes Handbuch zur Akteur-Netzwerk-Theorie. Bielefeld: Transcript.

Beyrau, D., 1993. Intelligenz und Dissens. Die russischen Bildungsschichten in der Sowjetunion 1917-1985. Göttingen: Vandenhoeck \& Ruprecht.

Bohn, T. M., 2008. Minsk - Musterstadt des Sozialismus. Stadtplanung und Urbanisierung in der Sowjetunion nach 1945. Köln, Weimar, Wien: Böhlau.

Bohn, T. M., 2014, 'Closed Cities versus Open Society?' The Interaction of DeStalinisation and Urbanisation' in Bohn, T. M.; Einax, R. and Abeßer, M. (eds.), De-Stalinisation Reconsidered. Persistence and Change in the Soviet Union. Frankfurt/Main, New York: Campus Verlag, pp. 115-131.

Bohn, T. M., Einax, R. and Abeßer, M., 2014. From Stalinist Terror to Collective Constraints. 'Homo Sovieticus' and the 'Soviet People' after Stalin, in Bohn, T. M., Einax, R. and Abeßer, M. (eds.), De-Stalinisation Reconsidered. 
Persistence and Change in the Soviet Union. Frankfurt/Main, New York: Campus Verlag, pp. 11-27.

Bon T. M., 2013. «Minskii fenomen». Gorodskoe planirovanie i urbanizatsiia v Sovetskom Soiuze posle Vtoroi mirovoi voiny. Moskva: ROSSPEN.

Broszat, M., 1981. Resistenz und Widerstand. Eine Zwischenbilanz des Forschungsprojekts, in Id., E. Fröhlich, A. Grassmann eds., Bayern in der NSZeit. IV. Herrschaft und Gesellschaft im Konflikt. Vol. C. 4. München, Wien: Oldenbourg, pp. 691-709.

Broszat, M., 1987. Einleitung: Gesellschaftsgeschichte des Widerstands, in Id. and E. Fröhlich eds., Alltag und Widerstand. Bayern im Nationalsozialismus. München: Piper, pp. 11-73.

D’iachenko, O. V., 1999. Piatidesiatnichestvo v Belarusi, in Id., Missionerskaia deiatel'nost' piatidesiatnicheskoj cerkvi v Belarusi. Mogilev: MGU im. A. A. Kuleshova.

D’iachenko, O. V., 2003. Piatidesiatnichestvo v Belarusi. Mogilev: MGU im. A. A. Kuleshova.

Davis, N., 1995. A Long Walk to Church. A Contemporary History of Russian Orthodoxy. Boulder, San Francisco, Oxford: Westview Press.

Eckert, R., 1995. Die Vergleichbarkeit des Unvergleichbaren. Die Widerstandsforschung über die NS-Zeit als methodisches Beispiel, in U. Poppe, R. Eckert, I. Kowalczuk eds., Zwischen Selbstbehauptung und Anpassung. Formen des Widerstandes und der Opposition in der DDR. Berlin: Ch. Links Verlag, pp. 68-84.

Einax R., 2011a. Savieckaja relihijnaja palityka i narodnaja relihijnaść u Bielarusi ŭ 1953-1964 hadach, Arche PAČATAK, 109, pp. 206-217.

Einax, R., 2011b. Von der Begegnung Davids mit dem sowjetischen Goliath. Kommunismus und Volksfrömmigkeit in Belarus, in T. M. Bohn, V. Shadurski eds., Ein weißer Fleck in Europa ... Die Imagination der Belarus als Kontaktzone zwischen Ost und West. Bielefeld: Transcript, pp. 193-202.

Einax, R., 2014. Entstalinisierung auf Weißrussisch. Krisenbewältigung, sozioökonomische Dynamik und öffentliche Mobilisierung in der Belorussischen Sowjetrepublik 1953-1965. Wiesbaden: Harrassowitz Verlag.

Fedorenko, F. I., 1965. Sekty, ich vera i dela. Moskva: Politicheskaia literatura.

Field, D. A., 2007. Private Life and Communist Morality in Khrushchevs Russia. New York: Lang. 
Figes, O., 2007. The Whisperers: Private Life in Stalin's Russia. New York: Metropolitan Books.

Fletcher, W. C., 1985. Soviet Charismatics. The Pentecostals in the USSR. New York, Berne, Frankfurt/Main: Peter Lang.

Grushin, B. A., 2001. Chetyre zhizni Rossii v zerkale oprosov obshchestvennogo mneniia. Ocherki massovogo soznaniia rossiian vremen Chrushcheva, Brezhneva, Gorbacheva $i$ El'tsina v 4-ch knigach. Zhizn' 1-aja: Epocha Khrushcheva. Moskva: Progress-Tradicija.

Grushin, B. A., 2003-2006. Chetyre zhizni Rossii v zerkale oprosov obshchestvennogo mneniia. Ocherki massovogo soznaniia rossiian vremen Chrushcheva, Brezhneva, Gorbacheva i El'tsina v 4-ch knigach. Zhizn'2-aja: Epocha Brezhneva. 2 vol. Moskva: Progress-Tradicija.

Hollenweger, W. J., 1997. Charismatisch-pfingstliches Christentum. Herkunft, Situation, ökumenische Chancen. Göttingen: Vandenhoeck \& Ruprecht.

Istoriia evangel'skikh khristian-baptistov v SSSR. Moskva: Vsesojuznyj Sovet Evangel'skich Christian-Baptistov 1989.

Kalugin, V. M., 1962. Sovremennoe religioznoe sektantstvo. Ego raznovisnosti i ideologiia. Moskva: Vysshaia shkola.

Kaściuk, M., 2000. Balšavickaja systema ǔlady na Bielarusi. Minsk: BP 'Ekaperspektyva' "Ekaperspektyva".

Kleßmann, C., 1996. Opposition und Resistenz in zwei Diktaturen in Deutschland, Historische Zeitschrift, 262, pp. 453-479.

Kostjuk, M. P., 2002. Bol'shevistskaia sistema vlasti v Belarusi. Moskva: Institut rossiiskoj istorii RAN.

Kotkin, S., 1995. Magnetic Mountain. Stalinism as a Civilization. Berkeley, Los Angeles, London: University of California Press.

Kowalczuk, I., 1995a. Artikulationsformen und Zielsetzungen von widerständigem Verhalten in verschiedenen Bereichen der Gesellschaft, Materialien der Enquete-Kommission 'Aufarbeitung von Geschichte und Folgen der SEDDiktatur in Deutschland'. Vol. VII/2. pp. 1203-1284.

Kowalczuk, I., 1995b. Von der Freiheit, Ich zu sagen. Widerständiges Verhalten in der DDR, in U. Poppe, R. Eckert, and I.-S. Kowalczuk, Zwischen Selbstbehauptung und Anpassung, Berlin: Verlag, pp. 85-115.

Kozlov, V. A., 2002. Mass Uprisings in the USSR. Protest and Rebellion in the Post-Stalin-Years. Armonk NY, London: Sharpe. 
Lane, C., 1978. Christian Religion in the Soviet Union. A Sociological Study. Albany NY: SUNY Press.

Latour, B., 2007. Eine neue Soziologie für eine neue Gesellschaft. Einführung in die Akteur-Netzwerk-Theorie. Frankfurt: Suhrkamp.

Lewin, M., 1985. The Making of the Soviet System. Essays in the Social History of Interwar Russia. London: Methuen.

Lewin, M., 1991a. Russia/USSR in Historical Motion: An Essay in Interpretation, Russian Review, 50, pp. 249-266.

Lewin, M., 1991b. The Gorbachev Phenomenon. A Historical Interpretation. Berkeley, Los Angeles CA: University of California Press.

Lindenberger, T., 1999. Die Diktatur der Grenzen. Zur Einleitung. In: Id. ed., Herrschaft und Eigen-Sinn in der Diktatur. Studien zur Gesellschaftsgeschichte der DDR. Köln, Weimar, Wien: Böhlau, pp. 13-44.

Luchterhandt, O., 1993. The Council for Religious Affairs, in S. P. Ramet ed., Religious Policy in the Soviet Union, pp. 55-83.

Lüdtke, A., 1993. Eigen-Sinn. Fabrikalltag, Arbeitererfahrungen und Politik vom Kaiserreich bis in den Faschismus. Hamburg: Ergebnisse.

Lüdtke, A., 1994. Geschichte und Eigensinn, in Berliner Geschichtswerkstatt ed., in H. Diekwisch, ed. Alltagskultur, Subjektivität und Geschichte. Zur Theorie und Praxis von Alltagsgeschichte. Münster: Westfälisches Dampfboot, pp. 139-153.

Luehrmann, S., 2015. Religion in Secular Archives. Soviet Atheism and Historical Knowledge. Oxford: Oxford University Press.

Plaggenborg S., 2006. Experiment Moderne. Der sowjetische Weg. Frankfurt/ Main, New York: Campus Verlag.

Poppe, U., Eckert, R. and Kowalczuk, I. eds., 1995. Zwischen Selbstbehauptung und Anpassung. Formen des Widerstandes und der Opposition in der DDR. Berlin: Ch. Links Verlag.

Prichiny sushchestvovaniia i puti preodeleniia religioznych perezhitkov, 1965. Minsk: Nauka i technika, pp. 162-208.

Ramet, S. P. ed., 1993. Religious Policy in the Soviet Union, Cambridge: Cambridge University Press.

Rittersporn, G., Rolf, M. and Behrends, J. C. eds., 2003. Sphären von Öffentlichkeit in Gesellschaften sowjetischen Typs. Zwischen partei-staatlicher Selbstinszenierung und kirchlichen Gegenwelten. Frankfurt/Main u.a.: Peter Lang. 
Sawatsky, W., 1981. Soviet Evangelicals Since World War II. Kitchener/ON: Wipf \& Stock Pub.

Sbornik zakonov Belorusskoi SSR i ukazov Prezidiuma Verchovnogo Soveta Belorusskoi SSR. 1938-1967 gg., 1969. Vol. 2. Minsk: Belarus’, p. 94.

Schlögel, K., 1984. Der renitente Held. Arbeiterprotest in der Sowjetunion 19531983. Hamburg: Junius.

Shirley, E. B. and Rowe Jr., M. eds., 1989. Candle in the Wind. Religion in the Soviet Union. Lanham MD, London: University Press of America.

Shlapentokh, V., 1989. Public and Private Life of the Soviet People. Changing Values in Post-Stalin-Russia. New York: Oxford University Press.

Sovremennoe sektantstvo i ego preodelenie. Po materialam ekspedicii v Tambovskuiu oblast' v 1959 g., 1961. Moskva [= Voprosy religii i ateizma, vol. 9].

Stephan, A., 2005. Von der Küche auf den Roten Platz. Lebenswege sowjetischer Dissidentinnen. Zürich: Pano-Verlag.

Stöver, B., 1997. Leben in deutschen Diktaturen. Historiographische und methodologische Aspekte der Erforschung von Widerstand und Opposition im Dritten Reich und der DDR, in D. Pollack, D. Rink eds., Zwischen Verweigerung und Opposition. Politischer Protest in der DDR 1970-1989. Frankfurt/Main, New York: Campus Verlag, pp. 30-53.

Vaj1, P., Genis, A., 1998. 60-e. Mir sovetskogo cheloveka. Izd. 2-oe, ispravl., Moskva.

Vysshie organy gosudarstvennoi vlasti i central'nogo upravleniia Belorusskoi SSR, 2003. Vol. 2. Minsk: BelNIIDAD, pp. 193-204.

Yurchak, A., 2005. Everything Was Forever, Until It Was No More. The Last Soviet Generation. Princeton, Oxford: Princeton University Press.

Zaslavsky, V., 1994. Closed Cities and the Organized Consensus, in Id., The NeoStalinist State. Class, Ethnicity, and Consensus in Soviet Society. With a New Introduction. Armonk/NY, pp. 130-164.

Zubkova, E., 1998. Russia After the War. Hopes, Illusions, and Disappointments, 1945-1957. Armonk/NY, London: Sharpe.

Zubkova, E., 2000. Poslevoennoe obshchestvo: politika i povsednevnost'. 19451953. Moskva: ROSSPEN. 